\title{
Keluhan Gangguan Kulit pada Pemulung Wanita Di Tempat Pembuangan Akhir (TPA) Terjun
}

\author{
Agnes Ferusgel $^{1 *}$, Rina Mahyurni Nasution ${ }^{2}$, Maria Butar-Butar ${ }^{3}$ \\ ${ }^{1,2}$ Institut Kesehatan Helvetia \\ ${ }^{3}$ Akademi Keperawatan Helvetia \\ e-mail: agneslppmhelvetia@gmail.com ${ }^{1 *}{ }^{*}$ rinamahyurni@yahoo.co.id $^{2}{ }^{\text {; maria_haryanthi@yahoo.com.au }}{ }^{3}$
}

\section{ARTICLE INFO}

\section{Article history:}

Received September 25, 2018

Revised November 25, 2018

Accepted November 26, 2018

\section{Keyword:}

Skin Disorders

Female Scavengers

Terjun Landfill

*) corresponding author

DOI:http://dx.doi.org/10.30604/jika.v3i2.127

\begin{abstract}
A B S T R A C T
Female scavengers at Terjun Landfill when working are still found who have not used a complete PPE and are still lacking in personal hygiene, this can cause health problems, one of which is complaints of skin disorders such as itching, redness, and burning. The hypothesis in this study is that there is a relationship between working period, personal hygiene, and the use of PPE with complaints of skin disorders in female scavengers at TPA Falls. This research is an analytic observational survey research with cross-sectional approach. The population and sample in this study were all 53 female scavengers carried out at the Terjun Landfill in Marelan, Medan. Analysis of the data used is a multiple linear regression test. The results showed that there was a relationship between personal hygiene $(p=0.022)$ and PPE use $(P=0.025)$ with complaints of skin disorders in female dwellers at Terjun Landfill Marelan, while there was no relationship between work expectations with complaints of skin disorders in female scavengers. The results showed the need for cross-sectoral cooperation to improve the health status of scavengers, one of which was by conducting socialization on occupational safety and health, including in terms of personal hygiene at work and the importance of using PPE for scavengers.
\end{abstract}

This is an open access article under the CC-BY-SA license.

\section{PENDAHULUAN}

Sampah merupakan seluruh sisa dari kegiatan manusia yang berbentuk padat, sesuatu yang tidak digunakan, tidak disenangi atau sesuatu yang dibuang yang berasal dari kegiatan manusia dan tidak terjadi dengan sendirinya. Jumlah kepadatan penduduk merupakan salah satu faktor yang dapat meningkatkan 
jumlah sampah, termasuk di perkotaan termasuk Kota Medan. Jumlah timbunan sampah pada 2009 mencapai 887,75 ton/hari dengan komposisi $47,2 \%$ organik dan 52,8 non organik. (Dinas Kebersihan Kota Medan). Masalah limbah kota menurut penelitian di Amerika semakin kompleks sejalan dengan pertambahan penduduk yang sangat pesat. Peningkatan jumlah sampah yang dihasilkan setiap orang di atas $2 \mathrm{~kg}$ dalam sehari. (Cunningham, Saigo, \& Cunningham, 2001)

Proses akhir dari rangkaian penanganan sampah yang biasa dijumpai di Indonesia adalah dilaksanakan di Tempat Pembuangan Akhir (TPA). Pada umumnya pemerosesan akhir sampah yang dilaksanakan di TPA adalah berupa proses landfilling (pengurugan), dan sebagian besar dilaksanakan dengan open-dumping, yang mengakibatkan permasalahan lingkungan. (Siregar, 2011)

Kota Medan merupakan kota terbesar di wilayah Provinsi Sumatera Utara, dengan luas wilayah lebih kurang $26.510 \mathrm{Km} 2$. TPA yang masih berfungsi saat ini di Kota Medan hanya TPA Terjun. TPA Terjun telah beroperasi sejak tahun 1993 dan sejak tahun 2013 TPA Terjun yang beroperasi menampung seluruh sampah dari 21 Kecamatan yang ada di Kota Medan. TPA Terjun berlokasi di Kelurahan Terjun Kecamatan Medan Marelan dengan luas 13,75 ha., dengan daya tampung 500.000 M. (Nasution, 2017)

Sistem pembuangan di TPA terjun adalah open dumping. Sistem open dumping adalah menumpuk sampah terus hingga tinggi tanpa dilapisi dengan lapisan geotekstil dan saluran lindi, sehingga ditumpuk begitu saja. Ketinggian tumpukan sampah saat ini sudah mencapai kirakira 7-8 meter tanpa pemilahan sampah, dengan air lindi yang tidak terolah dan tidak ada penanganan terhadap gas. Sistem pembuangan seperti itu menyebabkan pencemaran pada udara, tanah, dan air selain lahannya juga dapat menjadi tempat perkembangbiakan agent penyakit menular.
Setiap harinya diperkirakan sebanyak 200 orang pemulung datang untuk bekerja.

Pekerjaan pemulung jika dilihat dari segi kesehatan dan keselamatan kerjanya, berisiko tinggi untuk terkena berbagai penyakit akibat lingkungan kerja yang tidak kondusif dan kotor. Bukan hal itu saja, asupan gizi yang tidak baik mempermudah pemulung terjangkit berbagai penyakit seperti batuk, pilek, gatal-gatal, diare dan lain-lain dan tidak terkecuali pemulung wanita. (Sari \& Azrin, 2016)

Saat ini dalam memenuhi kebutuhannya para wanita tidak hanya bergantung kepada kepala keluarga saja, mereka juga turut serta membantu perekonomian keluarga. Tugas ganda yang diemban wanita yaitu sebagai ibu rumah tangga dan juga turut bekerja untuk membantu perekonomian keluarga membuat pemulung wanita lebih mudah lelah sehingga dapat menyebabkan daya tahan tubuh menurun dan dapat berisiko mengalami keluhan kesehatan. keluhan kesehatan yang dapat dialami oleh pemulung wanita antara lain keluhan kesehatan pernafasan, mata dan kulit.

Keluhan kulit yang dialami oleh pemulung wanita juga dapat disebabkan karena tidak menggunakan alat pelindung diri (APD) yang lengkap. APD sangat dibutuhkan oleh pemulung wanita dalam melindungi tubuh dari lingkungan fisik kerja yang panas dan dari risiko lingkungan biologi. Hasil penelitian Liswanti Tahun 2015 menyatakan bahwa kepatuhan penggunaan APD berhubungan dengan status kesehatan pada petugas pengumpul sampah rumah tangga di Kota Tasikmalaya. (Liswanti, 2015)

Keluhan-keluhan ini dapat juga disebabkan karena Pemulung tidak memperhatikan kesehatan dan keselamatan diri. Bau tidak sedap, benda-benda berbahaya yang mengandung zat kimia dan bakteri di tempat tumpukan sampah, dianggap tidak menjadi risiko bagi kesehatan mereka. Sebagai contoh, pemulung tidak mempedulikan kontak langsung antara kulit dengan 
genangan air sampah yang bau dan mengandung bakteri. Padahal, kontak tersebut dapat menyebabkan gatal-gatal atau infeksi kulit lainnya. (Faisal, \& Azrin, 2016),

Berdasarkan data Puskesmas Terjun Kecamatan Medan Marelan ada 3 jenis penyakit yang berhubungan dengan sampah yaitu Infeksi Saluran Pernafasan Akut (ISPA) sebagai penyakit terbesar di Puskesmas Terjun yaitu sebanyak 2898 kasus, diare yang merupakan urutan nomor 2 dari 10 penyakit terbesar sebanyak 1761 kasus dan penyakit kulit sebanyak 137 kasus yang merupakan penyakit urutan ke 9 dari 10 penyakit terbesar. Berdasarkan data karakteristik pasien didapatkan bahwa rata-rata penderita penyakit kulit bekerja sebagai pemulung (Puskesmas Terjun, 2016)

Pemulung wanita di TPA Terjun, pada saat bekerja masih ditemukan yang kurang lengkap dalam penggunaan APD. Berdasarkan fungsinya beberapa macam APD yang perlu digunakan oleh pemulung antara lain topi, alat pelindung tangan, dan alat pelindung kaki seperti sepatu boot khusus yang digunakan oleh petugas pada pekerjaan yang membutuhkan keamanan oleh zat kimia korosif, bahan-bahan yang dapat menimbulkan dermatitis (Tarwaka, 2014). Hal lain yang menjadi permasalahan lainnya yaitu masih kurang menjaga kebersihan diri, hal ini dapat menyebabkan timbulnya gangguan kesehatan, salah satu nya adalah keluhan kesehatan kulit seperti gatal, kemerahan dan terbakar. Penelitian ini bertujuan untuk menentukan faktor yang mempengaruhi terjadinya keluhan gangguan kulit pada pemulung wanita di TPA Terjun.

\section{METODE}

Penelitian ini merupakan penelitian survei observasional analitik dengan pendekatan cross sectional. Hasil observasi yang dilakukan yaitu masih ditemukan pemulung yang tidak menggunakan APD dengan lengkap. Populasi dan sampel dalam penelitian ini adalah seluruh pemulung wanita sebanyak 53 orang yang dilaksanakan di TPA Terjun Marelan Medan Pada Bulan Mei 2018. Tehnik pengumpulan dengan wawancara kepada pemulung wanita. Daftar pedoman pertanyaan diadopsi dari penelitian (Maryani, 2015) dan penelitian (Zebua, 2014), Analisis data yang digunakan adalah uji regresi linear berganda.

\section{HASIL DAN PEMBAHASAN}

Tabel 1.

Distribusi Frekuensi Berdasarkan Umur Pemulung Wanita di TPA Terjun.

\begin{tabular}{lcc}
\hline \multicolumn{1}{c}{ Kelompok Umur } & n & \% \\
\hline 19-24 tahun & 1 & 1,9 \\
25-30 tahun & 7 & 13,2 \\
31-36 tahun & 10 & 18,9 \\
37-42 tahun & 19 & 35,8 \\
43-48 tahun & 13 & 24,5 \\
49-54 tahun & 1 & 1,9 \\
55-60 tahun & 2 & 3,8 \\
\hline \multicolumn{1}{c}{ Jumlah } & $\mathbf{5 3}$ & $\mathbf{1 0 0 . 0}$
\end{tabular}

Berdasarkan Tabel 1 didapatkan bahwa mayoritas berdasarkan kelompok umur pemulung wanita di TPA Terjun mayoritas berusia 37-42 tahun sebanyak 19 orang ( $35,8 \%$ ) dan pada usia lanjut usia 55-60 tahun ditemukan sebanyak 2 orang $(3,8 \%)$.

Tabel 2.

Distribusi Frekuensi Berdasarkan Pendidikan Pemulung Wanita

\begin{tabular}{lcc}
\hline \multicolumn{1}{r}{ Pendidikan } & n & \% \\
\hline Tidak tamat SD & 3 & 5,7 \\
Tamat SD & 22 & 41,5 \\
Tamat SMP & 24 & 45,3 \\
Tamat SMA & 4 & 7,5 \\
\hline Jumlah & $\mathbf{5 3}$ & $\mathbf{1 0 0 . 0}$ \\
\hline
\end{tabular}

Berdasarkan Tabel 2 didapatkan bahwa mayoritas berdasarkan pendidkan pemulung wanita di TPA Terjun mayoritas pemulung sudah tamat SMP sebanyak 24 orang $(45,3 \%)$, tamat SD sebanyak 22 orang $(41,5 \%)$, tamat SMA 4 orang $(7,5 \%)$ dan tidak tamat SD sebanyak 3 orang $(5,7 \%)$. 
Tabel 3.

Distribusi Frekuensi Berdasarkan Masa Kerja Pemulung Wanita

\begin{tabular}{rcc}
\hline Masa Kerja & $\mathbf{n}$ & $\mathbf{\%}$ \\
\hline 2-4 tahun & 4 & 7,5 \\
5-7 tahun & 17 & 32,1 \\
8-10 tahun & 14 & 26,4 \\
11-13 tahun & 8 & 15,1 \\
14-16 tahun & 3 & 5,7 \\
17-19 tahun & 3 & 5,7 \\
20-23 tahun & 4 & 7,5 \\
\hline Jumlah & $\mathbf{5 3}$ & $\mathbf{1 0 0 , 0}$ \\
\hline
\end{tabular}

Berdasarkan Tabel 3 didapatkan bahwa mayoritas berdasarkan masa kerja pemulung wanita di TPA Terjun mayoritas sudah 5-7 tahun sebanyak 17 orang $(32,1 \%)$.

Gambaran Hygiene perorangan dan penggunaan APD responden pada penelitian ini dapat dilihat pada Tabel 4 berikut:

Tabel 4.

Distribusi Frekuensi Berdasarkan Hygiene Perorangan Pemulung Wanita di TPA Terjun

\begin{tabular}{lcccccc}
\hline \multirow{2}{*}{ Pertanyaan } & \multicolumn{2}{c}{ Ya } & \multicolumn{3}{c}{ Kadang } & \multicolumn{2}{c}{ Tidak } \\
\cline { 2 - 7 } & $\mathbf{n}$ & $\mathbf{\%}$ & $\mathbf{n}$ & $\mathbf{\%}$ & $\mathbf{n}$ & $\mathbf{\%}$ \\
\hline Mandi teratur & 51 & 96,2 & 2 & 3,8 & 0 & 0,0 \\
$\begin{array}{l}\text { Mandi dengan } \\
\text { sabun }\end{array}$ & 49 & 92,5 & 4 & 7,5 & 0 & 0,0 \\
$\begin{array}{l}\text { Mencuci tangan } \\
\text { sebelum makan }\end{array}$ & 43 & 81,1 & 8 & 15,1 & 2 & 3,8 \\
$\begin{array}{l}\text { Mencuci tangan } \\
\text { setelah bekerja }\end{array}$ & 13 & 24,5 & 26 & 49,1 & 14 & 26,4 \\
$\begin{array}{l}\text { Menggunkan } \\
\text { sabun setiap } \\
\text { kali mencuci } \\
\text { tangan }\end{array}$ & 0 & 0,0 & 24 & 45,3 & 29 & 54,7 \\
\hline
\end{tabular}

Berdasarkan Tabel 4 didapatkan bahwa mayoritas hygiene perorangan pemulung wanita di TPA Terjun mayoritas menjawab ya pada pernyataan mandi secara teratur (minimal 2 kali sehari) sebanyak 51 orang $(96,2 \%)$ dan mayoritas menjawab kadangkadang pada pernyataan mencuci tangan setelah bekerja sebanyak 26 orang $(49,1 \%)$.
Tabel 5.

Distribusi Frekuensi Penggunaan APD Pemulung Wanita di TPA Terjun

\begin{tabular}{|c|c|c|c|c|c|c|}
\hline \multirow{2}{*}{ Pertanyaan } & \multicolumn{2}{|c|}{ Ya } & \multicolumn{2}{|c|}{$\begin{array}{c}\text { Kadang- } \\
\text { kadang }\end{array}$} & \multicolumn{2}{|c|}{ Tidak } \\
\hline & $\mathbf{n}$ & $\%$ & $\mathbf{n}$ & $\%$ & $\mathbf{n}$ & $\%$ \\
\hline $\begin{array}{l}\text { Memakai } \\
\text { pakaian } \\
\text { pelindung }\end{array}$ & 32 & 60,4 & 9 & 17,0 & 12 & 22,6 \\
\hline $\begin{array}{l}\text { Pakaian } \\
\text { menutupi } \\
\text { tubuh }\end{array}$ & 19 & 35,8 & 24 & 45,3 & 10 & 18,9 \\
\hline $\begin{array}{l}\text { Sarung } \\
\text { tangan }\end{array}$ & 12 & 22,6 & 30 & 56,6 & 11 & 20,8 \\
\hline Masker & 14 & 26,4 & 24 & 45,3 & 15 & 28,3 \\
\hline
\end{tabular}

Berdasarkan Gambar 2 didapatkan bahwa mayoritas jawaban perilaku penggunaan APD pemulung wanita di TPA Terjun mayoritas menjawab ya pada pernyataan memakai pakaian pelindung/ pakaian kerja setia kali bekerja sebanyak 32 orang $(60,4 \%)$. Mayoritas menjawab kadang-kadang pada pernyataan menggunakan sarung tangan sebanyak 30 orang $(56,6 \%)$ dan mayoritas tidak menggunakan masker sebanyak 15 orang $(28,3 \%)$.

Gambaran keluhan kulit responden pada penelitian ini dapat dilihat pada Tabel 6 berikut:

Tabel 6.

Distribusi Frekuensi Keluhan Gatal Kulit pada Pemulung Wanita di TPA Terjun

\begin{tabular}{lcccc}
\hline \multirow{2}{*}{ Pertanyaan } & \multicolumn{2}{c}{ Ya } & \multicolumn{2}{c}{ Tidak } \\
\cline { 2 - 5 } & $\mathbf{n}$ & $\mathbf{\%}$ & $\mathbf{n}$ & $\mathbf{\%}$ \\
\hline Sering keluhan gatal & 42 & 79,2 & 11 & 20,8 \\
Gatal disertai nanah & 4 & 7,5 & 49 & 92,5 \\
$\begin{array}{l}\text { Gatal disertai bintik- } \\
\text { bintik padat }\end{array}$ & 31 & 58,5 & 22 & 41,5 \\
$\begin{array}{l}\text { Gatal terjadi saat } \\
\text { berkeringat }\end{array}$ & 11 & 20,8 & 42 & 79,2 \\
\hline
\end{tabular}

Berdasarkan Tabel 6 didapatkan bahwa mayoritas pemulung mengalami keluhan gatal sebanyak 42 orang $(79,2 \%)$ dengan disertai nanah sebanyak 4 orang $(7,5 \%)$, disertai dengan bintik-bintik padat sebanyak 31 orang $(58,5 \%)$ dan terjadi pada saat berkeringat sebanyak 11 orang $(20,8 \%)$. 
Hasil peneltian ini sesuai dengan penelitin yang dilakukan oleh Eka Lestari (2012) bahwa pada pemulung sering ditemukan Gangguan kulit seperti tinea versikolor, tinea versikolor, scabies, tinea korporis, tinea falvalis, candidiasis, karbonkel, folikulitis, dan miliria rubra yang disebabkan karena jamur, parasit dan aktivitas keringat yang berlebih.

Keluhan kulit pada pemulung juga dapat disebabkan kontak dengan sampah ataupun dengan air yang tercemar disekitar lokasi kerja TPA, yang juga dapat dikaitkan dengan personal hygiene dan lingkungan kerja serta rumah.

Hasil penelitian menunjukkan bahwa ada beberapa pemulung yang keluhan gatal disertai nanah. Rasa gatal menyebabkan para pemulung tidak nyaman dan biasanya penderita tidak tahan dan berusaha untuk menggaruknya, dan menyebabkan timbulnya infeksi dan tampak terjadi penanahan.

Tabel 7.

Distribusi Frekuensi Keluhan Kemerahan Kulit pada Pemulung Wanita di TPA Terjun

\begin{tabular}{lcccc}
\hline \multirow{2}{*}{ Pertanyaan } & \multicolumn{2}{c}{ Ya } & \multicolumn{2}{c}{ Tidak } \\
\cline { 2 - 5 } & $\mathbf{n}$ & $\boldsymbol{\%}$ & $\mathbf{n}$ & $\boldsymbol{\%}$ \\
\hline $\begin{array}{l}\text { Kulit sering } \\
\text { kemerahan }\end{array}$ & 35 & 66,0 & 18 & 34,0 \\
$\begin{array}{l}\text { Kemerahan pernah } \\
\text { terjadi di siang hari }\end{array}$ & 35 & 66,0 & 18 & 34,0 \\
$\begin{array}{l}\text { Kulit pernah terasa } \\
\text { terbakar }\end{array}$ & 44 & 83,0 & 9 & 17,0 \\
$\begin{array}{l}\text { Kulit pernah } \\
\text { Kemerahan dan gatal }\end{array}$ & 31 & 58,5 & 22 & 41,5 \\
\hline
\end{tabular}

Berdasarkan Tabel 7 didapatkan bahwa mayoritas pemulung mengalami kulit terasa terbakar sebanyak 44 orang $(83,0 \%)$. Pada saat siang hari terik panas matahari membakar kulit para pemulung yang tidak tertutupi, hal ini yang menyebabkan kulit merah dan terbakar terlebih bagian kulit telapak tangan dan wajah.

Kulit kemerahan merupakan perlindungan tahap awal bagi tubuh dari segala bakteri, efek negatif sinar ultraviolet, dan lain-lain. Sinar matahari merupakan sumber radiasi ultraviolet yang bisa merusak sel-sel tubuh, pemaparan yang terlalu sering dan berlebihan dalam waktu singkat akan meyebabkan kulit yang tidak terlindungi menjadi kemerahan, terasa panas dan luka bakar karena matahari. (Yuniarti \& Anggraeni, 2018)

Faktor yang mempengaruhi gangguan kulit pada pemulung wanita di TPA Terjun berdasarkan hasil uji regresi linear berganda yaitu:

Tabel 8.

Hasil Uji Regresi Linear Faktor yang

Mempengaruhi Keluhan Gangguan Kulit pada

Pemulung Wanita di TPA Terjun

\begin{tabular}{lcc}
\hline \multicolumn{1}{c}{ Gangguan Kulit } & B & p \\
\hline Constanta & 2.692 & \\
Masa Kerja & 0,053 & 0,308 \\
Hygiene perorangan & 0,512 & 0,022 \\
Alat Pelindung Diri & 0,433 & 0,025 \\
\hline
\end{tabular}

Hasil penelitian menunjukkan adanya pengaruh hygiene perorangan $(\mathrm{p}=0,022)$ dan alat pelindung diri $(\mathrm{p}=0,025)$ terhadap keluhan gangguan kulit pada pemulung wanita di TPA Terjun, sedangkan masa kerja tidak berpengaruh dengan keluhan gangguan kulit pada pemulung wanita.

Hasil penelitian sejalan dengan penelitian yang dilakukan oleh Suhelmi yang menyatakan bahwa tidak terdapat hubungan antara masa kerja dengan keluhan gangguan kulit pada petani rumput laut di Kelurahan Kalumeme Kecamatan Ujung Bulu Kabupaten Bulukumba. (Suhelmi, 2014) Sedangkan penelitian ini bertolak belakang dengan penelitian yang dilakukan oleh Cahyawati dan Budiono Tahun 2011 menyatakan bahwa ada pengaruh masa kerja terhadap kejadian penyakit kulit.(Cahyawati \& Budiono, 2011)

Hasil penelitian ini sesuai dengan penelitian yang dilakukan oleh Catur yang menyatakan ada hubungan hygiene perorangan dengan keluhan kulit pada pekerja. Hasil penelitian ini juga sesuai dengan penelitian yang dilakukan oleh Catur di Jember menyatakan 
terdapat hubungan antara personal hygiene dengan kejadian penyakit kulit di Kecamatan Jelbuk Kabupaten Jember. (Catur, 2017)

Hygiene perorangan merupakan suatu perawatan diri terdiri dari perawatan kebersihan kulit kepala dan rambut, mata, hidung, telinga, kuku kaki dan tangan, kulit, perawatan tubuh secara keseluruhan (Mustikawati, 2013).

Hasil uji regresi menyatakan bahwa terdapat pengaruh hygiene perorangan terhadap keluhan gangguan kulit pada pemulung wanita di TPA Terjun dengan nilai regresi 0,512. Setiap pemulung wanita harus memiliki kesadaran diri untuk menjaga personal hygiene diri, kerena risiko lingkungan kerja yang buruk seperti banyak kotoran-kotoran, bakteri, jamur dan kuman yang dapat menyebkan pemulung wanita rentang mengalami penyakit khusunya penyakit kulit.

Para pemulung terbiasa mandi pada saat pagi hari dan malam hari, pada saat sampai di rumah para pemulung wanita tidak segera mandi, mereka mencuci tangan dan kaki untuk mengerjakan pekerjaan di rumah seperti memasak, mencuci pakaian, menyetrika, setelah menyelesaikan pekerjaan rumah, barulah membersihkan diri. Kebiasaan inilah yang menyebabkan bakteri maupun kuman yang dibawa dari tempat kerja terpajan begitu lama pada tubuh pemulung wanita.

Pemulung wanita mayoritas menyatakan bahwa rasa gatal yang mereka alami sering terjadi pada saat berkeringat. Hal ini dikarenakan pada saat tubuh berkeringat maka pakaian kerjapun terasa basah ataupun lembab, kelembapan inilah yang dapat menyebakan kuman dan bakteri berkembang dan dapat menyebakan gangguan kulit seperti rasa gatal. Belum lagi, mereka menyatakan bahwa baju yang mereka gunakan, belum tentu setiap hari diganti.

Hasil penelitian juga menyebutkan bahwa ada pengaruh antara penggunaan APD dengan keluhan keluhan gangguan kulit pada pemulung wanita di TPA Terjun dengan nilai regresi 0,433 . Hal ini juga sesuai dengan penelitian yang dilakukan oleh Aisyah Tahun 2012 yaitu ada hubungan yang bermakna antara umur pekerja, lama bekerja, pendidikan pekerja, kebersihan kulit saat bekerja, pemakaian pakaian kerja, pemakaian sarung tangan kerja dan pemakaian sepatu kerja dengan keluhan gangguan kulit di Kelurahan Pekan Labuhan Kecamatan Medan Labuhan Kota Medan. (Aisyah, Santi, \& Chahaya, 2012).

Hasil penelitian ini juga sesuai dengan penelitian yang dilakukan oleh Fielrantika yang menyatakan penggunaan APD yang rendah merupakan faktor resiko untuk timbulnya penyakit dermatitis kontak akibat kerja. (Fielrantika, 2017)

Alat pelindung diri adalah seperangkat alat keselamatan yang digunakan oleh pekerja untuk melindungi seluruh atau sebagian tubuhnya dari kemungkinan adanya pemaparan potensi bahaya lingkungan kerja terhadap kecelakaan dan penyakit akibat kerja Alat pelindung diri hanya digunakan untuk mengurangi tingkat keparahan dari suatu kemungkinan terjadinya kecelakaan atau penyakit akibat kerja.

Pada pemulung wanita di TPA Terjun masih ditemukan yang tidak selalu menggunakan pelindung diri saat bekerja. Ada beberapa dari mereka yang hanya menggunakan baju lengan pendek, sehingga pada saat mereka bekerja di siang hari, kulitpun terasa panas dan terbakar. Alat pelindung diri yang wajib digunakan oleh pemulung wanita antara lain topi untuk melindungi kepala dari terik matahari, penutup wajah untuk menghindari debu dan paparan sinar matahari, baju pelindung tertutup, sarung tangan dan sepatu boot.

Alat pelindung diri merupakan jalan akhir dalam pengendalian risiko bahaya kerja. Pada pemulung sendiri penggunaan APD untuk melindungi diri dari risiko lingkungan kerja yang berbahaya seperti terik panas matahari, menghindari kontak langsung dengan bakteri 
yang ada pada sampah yang dapat menyebabkan berbagai penyakit yang ditularkan dari lingkungan kepada pemulung seperti gatal-gatal pada kulit, terbakar oleh terik sinar matahari, dan lain sebagainya.

\section{KESIMPULAN DAN SARAN}

Keluhan kulit yang dialami oleh pemulung wanita di TPA terjun adalah keluhan gatal, kemerahan dan terasa terbakar. Hasil penelitian menunjukkan bahwa terdapat pengaruh hygiene perorangan, pengguaan APD (Alat Pelindung Diri) perorangan terhadap gangguan keluhan kulit pada pemulung wanita di TPA. Sedangkan, masa kerja tidak berpengaruh terhadap gangguan keluhan kulit pada pemulung wanita di TPA Terjun.

Diharapkan kepada Pemerintah perlu adanya kerjasama lintas sektoral untuk meningkatkan derajat kesehatan pemulung salah satunya dengan cara melakukan sosialisasi mengenai keselamatan dan kesehatan kerja termasuk didalamnnya mengenai kebersihan diri saat bekerja dan pentingnya penggunaan APD bagi pemulung.

Bagi pemulung diharapkan lebih memperhatikan personal hygiene dengan segera mencuci tangan dan kaki dengan air mengalir dan sabun setelah bekerja, mengganti pakaian kerja sekali sehari dan jangan mnyatukan pakaian kerja yang kotor degan pakaian lainnnya. Diharapkan para pemulung dapat meningkatkan kesadaran diri untuk menggunakan alat pelindung diri dengan lengkap.

Bagi peneliti selanjutnya dapat melakukan penelitian yang serupa dengan variable maupun pendekatan yang berbeda sehingga dapat menemukan temua-temuan baru.

\section{UCAPAN TERIMAKASIH}

Pada kesempatan ini, peneliti ucapkan terimakasih kepada Direktorat Riset dan Pengabdian Masyarakat, Direktorat Jendral Penguatan Riset dan Pengembangan sebagai pemberi Dana. Kami ucapkan terimaksih juga kepada Dinas Kebersihan dan Pertamanan Kota Medan dalam memberikan kesempatan penelitian di UPTD Terjun Marelan.

\section{DAFTAR PUSTAKA}

Aisyah, F., Santi, D. N., \& Chahaya, I. (2012). Hubungan Hygiene Perorangan Dan Pemakaian Alat Pelindung Diri Dengan Keluhan Gangguan Kulit Pada Pekerja Pengupas Udang Di Kelurahan Pekan Labuhan Kecamatan Medan Labuhan Tahun 2012. Lingkungan Dan Keselamatan Kerja, 2(2).

Cahyawati, I. N., \& Budiono, I. (2011). Faktor Yang Berhubungan Dengan Kejadian Dermatitis Pada Nelayan. Jurnal Kesehatan Masyarakat, 6(2).

Catur, W. Y. (2017). Hubungan Hygiene Perorangan Dan Pemakaian Alat Pelindung Diri Dengan Gangguan Kulit Pada Pekerja Ud. Ps Pindang Juwana Pati Tahun 2017. Skripsi, Fakultas Kesehatan.

Cunningham, W. P., Saigo, B. W., \& Cunningham, M. A. (2001). Environmental science: A global concern (Vol. 412). Book, McGrawHill Boston, MA.

Faisal, R., Faisal, R., \& Azrin, M. (2016). Persepsi Pemulung terhadap Aspek Kesehatan Keselamatan Kerja (K3) dalam Pengelolaan Sampah di Tempat Pembuangan Sementara (TPS) Kota Pekanbaru. Jurnal Online Mahasiswa Fakultas Kedokteran Universitas Riau, 3(1), 1-9.

Fielrantika, S. (2017). Hubungan Karakteristik Pekerja, Kelengkapan Dan Higienitas Apd Dengan Kejadian Dermatitis Kontak (Studi Kasus Di Rumah Kompos Jambangan 
Surabaya). The Indonesian Journal of Occupational Safety and Health (Vol. $6)$. Book. https://doi.org/10.20473/ijosh.v6i1.201 7.16-26

Liswanti, Y. (2015). Faktor-Faktor Yang Berhubungan Dengan Kepatuhan Penggunaan Alat Pelindung Diri (APD) Serta Kaitannya Terhadap Status Kesehatan Pada Petugas Pengumpul Sampah Rumah Tangga di Kota Tasikmalaya Tahun 2014. Jurnal Kesehatan Bakti Tunas Husada, 13(1).

Maryani, R. (2015). Hubungan Antara Personal Hyginen dan Pemakaian Alat Pelindung Diri dengan Kejadian Penyakit Kulit pada Pemulung di TPA Tanjung Rejo Kecamatan Jekulo Kabupaten Kudus. Jurusan IKM Fakultas Ilmu Keolahragaan Universitas Negeri Semarang.

Mustikawati, I. S. (2013). Perilaku personal hygiene pada pemulung di TPA kedaung wetan tangerang. In Forum Ilmiah (Vol. 10, pp. 1-9).

Nasution, N. H. (2017). Analisis Sistem Pengelolaan Sampah Di TPA Terjun Kecamatan Medan Marelan Kota Medan Tahun 2017.

Puskesmas Terjun. (2016). Laporan Tahunan Puskesmas Terjun. Medan: Puskesmas Terjun

Sari, I. K., \& Azrin, M. (2016). Gambaran Pengetahuan Pemulung terhadap Aspek Kesehatan Keselamatan Kerja (K3) dalam Pengelolaan Sampah di Tempat Pembuangan Sementara (Tps)
Kota Pekanbaru. Jurnal Online Mahasiswa Fakultas Kedokteran Universitas Riau, 3(1), 1-10.

Siregar, F. R. (2011). Analisis Kualitas Udara dan Keluhan Kesehatan yang Berkaitan dengan Saluran Pernapasan Pada Pemulung di Tempat Pembuangan Akhir Sampah (TPA) Namo Bintang Kecamatan Pancur Batu Kabupaten Deli Serdang Tahun 2011.

Suhelmi, R. (2014). Hubungan Masa Kerja, Higiene Perorangan dan Penggunaan Alat Pelindung Diri dengan Keluhan Gangguan Kulit Petani Rumput LAut di Kelurahan Kalumeme Bulukumba. Kesehatan Lingkungan Fakultas Kesehatan Masyarakat Universitas Hasanuddin.

Yuniarti, T., \& Anggraeni, T. (2018). Dampak Tempat Pembuangan Akhir Sampah Putri Cempo Surakarta Terhadap Penyakit Kulit Pada Masyarakat Mojosongo. Jurnal Infokes Apikes Citra Medika Surakarta, 8(1).

Tarwaka. (2014). Keselamatan dan Kesehatan Kerja: Manajemen dan Implementasi K3 di Tempat Kerja. Surakarta: Harapan Press.

Zebua, A. P. (2014). Hubungan Personal Hygiene dengan Keluhan Kulit pada Pemulung dan Fasilitas Sanitasi di Tpa Terjun Kelurahan Terjun Kecamatan Medan Marelan Tahun 2014. Lingkungan Dan Keselamatan Kerja, $3(2)$. 